\author{
연속순환 생물막 공정을 이용한 돈사 폐수 처리 \\ 고병대* . 라창식** \\ 강원도 농업기술원* \\ 강원대학교 동물생명자원과학부**
}

\title{
Swine Wastewater Treatment Using Continuos Circulation Biofilm Process
}

\author{
B. D. Goh* and C. S. Ra** \\ Agriculture and extension services* \\ Division of Animal Life Resource Science, Kangwon National University**
}

\begin{abstract}
A submerged biofilm sequencing batch reactor (SBSBR) process, which liquor was internally circulated through sandfilter, was designed, and performances in swine wastewater treatment was evaluated under a condition of no external carbon source addition. Denitrification of $\mathrm{NO}_{\mathrm{x}}-\mathrm{N}$ with loading rate in vertical and slope type of sandfilter was $19 \%$ and $3.8 \%$, respectively, showing approximately 5 times difference, and so vertical type sandfilter was chosen for the combination with SBSBR. When the process was operated under 15 days HRT, $105 \mathrm{~L} / \mathrm{hr}^{3} \mathrm{~m}^{3}$ of internal circulation rate and $54 \mathrm{~g} / \mathrm{m}^{3} . \mathrm{d}$ of $\mathrm{NH}_{4}-\mathrm{N}$ loading rate, treatment efficiencies of STOC, $\mathrm{NH}_{4}-\mathrm{N}$ and $\mathrm{TN}$ (as $\mathrm{NH}_{4}-\mathrm{N}$ plus $\mathrm{NO}_{\mathrm{x}}-\mathrm{N}$ ) was $75 \%, 97 \%$ and $85 \%$, respectively. By conducting internal circulation through sandfilter, removal performances of $\mathrm{TN}$ were enhanced by $14 \%$, and the elevation of nitrogen removal was mainly attributed to occurrence of denitrification in sandfilter. Also, approximately $57 \%$ of phosphorus was removed with the conduction of internal circulation through sandfilter, meanwhile phosphorus concentration in final effluent rather increased when the internal circulation was not performed. Therefore, It was quite sure that the continuous internal circulation of liquor through sandfilter could contribute to enhancement of biological nutrient removal. Under $60 \mathrm{~g} / \mathrm{m}^{3}$.d of $\mathrm{NH}_{4}-\mathrm{N}$ loading rate, the $\mathrm{NH}_{4}-\mathrm{N}$ level in final effluent was relatively low and constant (below $20 \mathrm{mg} / \mathrm{L}$ ) and over $80 \%$ of nitrogen removal was maintained in spite of loading rate increase up to $100 \mathrm{~g} / \mathrm{m}^{3}$.d. However, the treatment efficiency of nitrogen was deteriorated with further increase of loading rate. Based on this result, an optimum loading rate of nitrogen for the process would be $100 \mathrm{~g} / \mathrm{m}^{3} . \mathrm{d}$. (Key words : Swine wastewater, Biofilm, SBR, Sandfilter)
\end{abstract}

$\begin{array}{cl}\text { I . 서 론 } & \text { 체 · 축산농가 단위에서 환경오염문제 예방을 } \\ & \text { 위해 많은 노력을 해오고 있다. 현재 국내에서 } \\ \text { 최근 들어 축산업이 전업·기업적 형태로 발 } & \text { 는 49개의 축산폐수공공처리장이 운전 중에 있 } \\ \text { 전함에 따라 국소적으로 발생하는 축산폐수의 } & \text { 으며 대부분이 주 처리공정으로서 생물학적 처 } \\ \text { 양이 증가하고 그 처리가 어려워 국가. 지자 } & \text { 리공정이 이용되고 있다. 또한 개인 축산농가 }\end{array}$

Corresponding author : C. S. Ra, Division of Animal Life Resource Science, Kangwon National University, Chunchon, 200-701, Korea.

Tel: 033-250-8618, Fax: 033-244-2433, E-mail: changsix@kangwon.ac.kr 
나 단지에서도 일부 생물학적 공정이 설비되어 운전되고 있는데 향후 축산분뇨의 해양투기가 2008년을 기점으로 전면 금지되고 현재의 해양 투기비용도 매우 높아 점차 농가들이 대안마련 에 고심하고 있으며 농가현장 단위의 생물학적 정화처리 공정에 대한 관심이 날로 빠르게 증 가하고 있다. 또한 축산농가에서는 전염성 가 축질병이 지속적으로 발생하고 이로 인하여 막 대한 경제적 손실을 경험함에 따라 물을 이용 하여 축사를 주기적으로 청소하여 청결을 유지 하고 질병발생을 제어할 수 있는 flushing 축사 형태로의 전환을 실질적으로 원하고 있다. 그 러나 물 사용에 따른 폐수량의 증가와 그 처리 에 대한 부담으로 엄두를 내지 못하고 있어 flushing 축사로부터 배출되는 폐수를 효율적으 로 처리할 수 있는 농가형 정화처리 기술이 개 발되기를 기대하고 있다.

그동안 축산농가 현장에 다양한 공정이 적용 되어 왔으나 농가단위에서 처리에 어려움을 겪 는 원인은 고농도 질소. 인의 제거를 위한 외 부탄소원의 사용으로 처리비용이 높을 뿐만 아 니라 처리시스템으로부터 잉여슬러지 인발에 의한 적정 SRT 유지, 농가에서 사용하는 소독 제 등에 함유된 저해물질에 의한 독성작용 제 어, 적정량의 외부 탄소원 공급, 침전 중 탈질 에 의한 슬러지 부상방지 등 처리시스템을 효 율적으로 관리할 전문 인력이 없기 때문이다. 따라서 축산농가 단위에 효과적으로 적용되어 운전될 수 있는 농가형 축산폐수처리공정은 처 리공정이 복잡하지 않아 비전문가라도 운전조 작이 용이하고 저해물질의 독성효과에 저항성 이 강하며 SRT 유지를 위한 슬러지 인발이 없 고 최소의 외부 탄소원 공급으로 운전비용이 낮아야하는 등의 농가현장 실정에 적합하여야 할 것이다.

미생물 부착을 위한 고정 혹은 유동담체를 지니고 있는 생물막 공정은 생활하수와 산업폐 수로부터의 질소와 유기물 제거에 효과적인 것 으로 알려지고 있다 (Buitron 등, 2004; Loukidou 와 Zouboulis, 2001; White와 Shadabel, 1998). 침 수형 생물막 공정의 장점은 부유성장 공정에 비해 반응기내 미생물의 수가 많아 높은 대사
활성을 유지할 수 있으며 (Li 등, 2003; Andrea 등, 2000) 다양한 미생물 군으로 이루어진 생물 막내 먹이사슬이 길어 공정의 안정성을 얻을 수 있고(Cohen, 2001) 반응기내 미생물의 체류 시간이 길뿐만 아니라 과잉 슬러지의 발생이 적으며 (Wang 등, 1998) 생물막내에 호기적 구 역과 무산소 구역이 존재함에 따라 질산화와 탈질이 동시에 일어날 수 있다 $(\mathrm{Li}$ 등, 2003)는 것이다. 또한 생물막 공정은 운전 중 슬러지 부상문제가 발생하지 않으며 독성물질에 대한 저항성이 강해 유지관리가 쉽다는 장점을 지니 고 있다 $(\mathrm{Li}$ 등, 2003; Loukidou와 Zouboulis, 2001). 이러한 점으로 미뤄 판단할 때 농가단위 의 축산폐수처리를 위해서는 기존의 부유성장 공정보다는 생물막 공정을 활용하는 것이 효율 적일 것으로 여겨진다.

침수형 생물막 공정과 유사하나 운전방법에 서 차이가 있는 생물여과 공정은 주로 생활하 수를 대상으로 유출수내 잔류 오염물질과 부유 물 및 유기물의 제거를 목적으로 많이 사용되 어 왔으며 (Ling과 Chen, 2005; Gomez 등, 2003) 최근에는 모래여과공정과 같은 생물여과 공정 을 이용한 질소 제거 방법이 보고되고 있다 (Nakhla와 Farooq, 2003). 그러나 모래여과 공정 을 이용한 질소 제거에 대한 연구보고는 많지 않으며 더욱 생물막 공정이나 생물여과 공정을 축산폐수 처리에 활용한 기술에 관한 보고는 매우 드물다.

따라서 본 연구에서는 단일 반응조로 이루어 져 공정과 운전이 간단한 $\mathrm{SBR}$ 에 생물막을 도 입한 SBSBR(Submerged Biofilm Sequencing Batch Reactor) 반응조와 모래여과조를 연계하 여 내부 순환형으로 운전하는 공정을 고안하고 flushing 돈사로부터 배출되는 폐수를 처리하는 데 있어서의 오염물질 제거 양상과 처리효율을 평가하였다.

\section{ㅍ. 재료 및 방법}

시험된 공정은 침수생물막 연속회분식 반응 조 (submerged biofilm sequencing batch reactor, SBSBR)와 sandfilter로 구성되었다(Fig. 1). 생물 


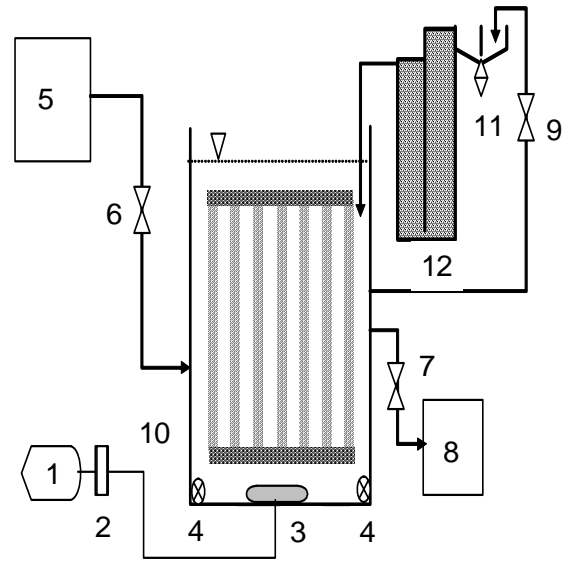
1. aerator
7. effluent decanting pump
2. air flow regulator
8. effluent storage bucket
3. air diffuser
9. circulation pump
4. submerged mixer
10. biofilm SBR
5. influent bucket
11. coarse sludge screen
6. influent loading pump 12. sandfilter

Fig. 1. Schematic diagram of experimental apparatus.

막 SBR 반응조는 polyethylene 재질로 유효용적 $50 \mathrm{~L}$ 이었으며 공기의 공급과 교반을 위하여 반 응기 내부에 산기장치와 교반기가 설비되었다. 유입수의 유입과 처리수의 배출 및 liquor의 내 부순환은 연동펌프를 이용하여 이루어졌다. SBR 반응기 내부에 미생물 부착성장을 위한 biofilm media를 고정하기 위하여 PVC 구조물 을 제작 설치하였으며 biofilm media로 총 $12.7 \mathrm{~m}$ 의 ring lace (Hyosung, Inc.)를 설비하였다. 시험에 사용된 ring lace는 nylon 재질의 직경 $45 \mathrm{~mm}$, minimum surface area $1 \mathrm{~m}^{2} / \mathrm{m}$ 의 규격을 지니고 있었다.

Sandfilter 장치의 총 용적은 $12 \mathrm{~L}$ 이었으며 내
부에 $3 \mathrm{~mm}$ 이상의 모래를 충전하여 사용하였 다. SBSBR과 연계된 sand filter는 계단식의 수 직형태로서 연동펌프로 유입된 liquor의 순환은 하향류-상향류로 자연압에 의해 이루어지게 하였다. 생물막으로부터 탈리된 sludge가 sandfilter로 유입되어 막히는 현상을 예방하기 위하 여 filter 입구에 나일론 직물로 충전된 매우 작 은 prefilter를 설치하였으며 filter의 역세척은 순 환수의 flow rate이 늦어짐이 목격될 때 최종 유출수를 이용하여 수행하였다.

SBSBR은 Table 1에 나타낸 것과 같은 sequence로 운전하였으며 외부탄소원의 공급 없 이 실험을 진행하였다. 호기적 처리과정에서는 최소 $2.0 \mathrm{mg} / \mathrm{L}$ 이상의 용존 산소가 유지되도록 하였다. 운전초기 돈사폐수 처리를 위해 설비 된 pilot 규모의 SBR에서 $\mathrm{MLSS}$ 를 채취하여 설 비된 순환형 SBSBR 시스템에 접종하였고 시스 템을 HRT 15일 조건에서 운전하면서 충분한 생물막 형성이 이루어진 후 시스템의 성능평가 와 특성 분석이 행하여졌다. 우선 sand filter를 통한 내부 순환 없이 HRT 15일 조건에서 운전 하면서 단일 SBSBR에서의 오염물질 제거효율 과 그 특성을 파악하였으며 (operation I) 그 후 sand filter와 SBSBR을 연계시키고 HRT 15일 조건에서 liquor의 내부순환을 연동펌프를 이 용하여 22시간동안 (침전과 최종 처리수 배출 을 제외한 모든 처리단계) $105 \mathrm{~L} / \mathrm{hr} \cdot \mathrm{m}^{3}$ 비율(sandfilter 용적 기준)로 시행하면서 처리효율과 특 성을 분석하였다 (operation II).

단일 SBSBR에서의 오염물질 제거효율 평가 시험동안 sandfilter내 미생물의 성장을 유도하 기 위하여 SBSBR로부터 배출되는 유출수를 sandfilter를 통하여 배출하였다. 또한, SBSBR과 연계되어 운전할 sandfilter의 운전형태를 결정 하기 위하여 수직형과 경사형 두 유형의

Table 1. Operational sequence of system

\begin{tabular}{|c|c|c|c|c|c|}
\hline Condition & Feeding (0.1 hr) & Reaction (22 l & & $\begin{array}{c}\text { Sludge settle } \\
\quad(1.8 \mathrm{hr})\end{array}$ & $\begin{array}{c}\text { Discharge } \\
\text { (0.1 hr) }\end{array}$ \\
\hline Aeration & NA* & NA $(6 \mathrm{hr}) \quad \mathrm{A}(14 \mathrm{hr})$ & NA (2 hr) & & \\
\hline Mixing & $\mathrm{NM}^{* *}$ & $\mathrm{M}(6 \mathrm{hr}) \quad \mathrm{NM}(14 \mathrm{hr})$ & $\mathrm{M}(2 \mathrm{hr})$ & & \\
\hline
\end{tabular}

*NA : no aeration, ${ }^{* *} \mathrm{NM}:$ no mixing 
Table 2. Influent characteristics and removal efficiencies

Operation I

\begin{tabular}{|c|c|c|c|c|c|c|c|c|c|}
\hline \multirow{2}{*}{$\begin{array}{c}\text { Parameter } \\
\text { (mg/L) }\end{array}$} & \multicolumn{4}{|c|}{ Influent } & \multicolumn{4}{|c|}{ Effluent } & \multirow{2}{*}{$\begin{array}{c}\text { Removal } \\
\text { (\%) }\end{array}$} \\
\hline & Means & Min & Max & St. Dev & Means & Min & Max & St. Dev & \\
\hline TOCs & 428.6 & 241.85 & 615.52 & 111.66 & 157.24 & 137.81 & 180.12 & 11.92 & 63.33 \\
\hline $\mathrm{NH}_{4}^{+}$ & 819.99 & 627.31 & 993.69 & 104.44 & 26.99 & 0.0 & 60.47 & 20.9 & 96.76 \\
\hline $\mathrm{NO}_{\mathrm{x}}^{-}$ & 4.39 & 0.0 & 7.11 & 2.12 & 238.18 & 34.48 & 259.19 & 89.82 & - \\
\hline $\mathrm{PO}_{4}^{3-}$ & 10.97 & 6.23 & 23.06 & 4.05 & 25.25 & 21.37 & 28.15 & 1.91 & - \\
\hline${ }^{*} \mathrm{~T}-\mathrm{N}$ & 824.38 & 627.31 & 1000.80 & 104.98 & 265.17 & 34.48 & 319.66 & 91.56 & 67.83 \\
\hline
\end{tabular}

\section{Operation II}

\begin{tabular}{|c|c|c|c|c|c|c|c|c|c|}
\hline \multirow{2}{*}{$\begin{array}{c}\text { Parameter } \\
\text { (mg/L) }\end{array}$} & \multicolumn{4}{|c|}{ Influent } & \multicolumn{4}{|c|}{ Effluent } & \multirow{2}{*}{$\begin{array}{c}\text { Removal } \\
\text { (\%) }\end{array}$} \\
\hline & Means & Min & Max & St. Dev & Means & Min & Max & St. Dev & \\
\hline "TOCs & 600.63 & 417.90 & 689.80 & 91.65 & 171.57 & 158.60 & 188.20 & 8.37 & 70.78 \\
\hline $\mathrm{NH}_{4}^{+}$ & 814.04 & 723.56 & 949.93 & 93.69 & 12.11 & 0.0 & 56.90 & 17.58 & 98.51 \\
\hline $\mathrm{NO}_{\mathrm{x}}^{-}$ & 0.0 & 0.0 & 0.0 & 0.0 & 140.03 & 109.36 & 162.36 & 18.02 & - \\
\hline $\mathrm{PO}_{4}^{3-}$ & 70.66 & 67.55 & 73.54 & 1.84 & 30.39 & 27.36 & 33.80 & 1.78 & 57.13 \\
\hline${ }^{*} \mathrm{~T}-\mathrm{N}$ & 814.04 & 723.56 & 949.93 & 93.69 & 152.14 & 0.0 & 219.26 & 55.60 & 81.31 \\
\hline
\end{tabular}

* T-N as $\mathrm{NH}_{4}-\mathrm{N}$ plus $\mathrm{NO}_{\mathrm{x}}-\mathrm{N}$.

sandfilter를 시험하여 filter의 적정운전형태를 결정하였다.

유입수로는 flushing 돈사로부터 배출된 폐수 를 침전시킨 후 그 상등액을 사용하였으며 그 성상은 Table 2에 나타나있다. 채취된 시료는 $4^{\circ} \mathrm{C}$ 냉장고에 보관하였으며 가능한한 각 분석 항목에 대하여 7일내에 분석이 완료되도록 하 였다. STOC (soluble total organic carbon) 분석 을 위해 TOC 분석기 (TOC-5000A, shimadzu)가 사용되었으며, $\mathrm{NH}_{4}-\mathrm{N}, \mathrm{NO}_{\mathrm{x}}-\mathrm{N}, \mathrm{PO}_{4}^{3-}$ 분석은 자 동수질분석기 (Zellweger: Lachat, QuickChem 8000)를 이용하여 이루어졌다. 고형물 분석은 Standard method (American public health association (A.P.H.A), 1995)에 의거 이루어졌다.

\section{III. 결과 및 고찰}

Fig. 2는 시스템으로 슬러지를 접종한 후 초 기 적응기간 동안 sandfilter를 통한 내부순환이 없는 조건하에서의 SBSBR내의 MLSS 농도와 질산화율의 변화를 나타낸 것이다. 초기 약 $2,100 \mathrm{mg} / \mathrm{L}$ 수준의 MLSS 농도는 30일경까지는 별다른 변화를 보이지 않다가 운전일수 40 일경

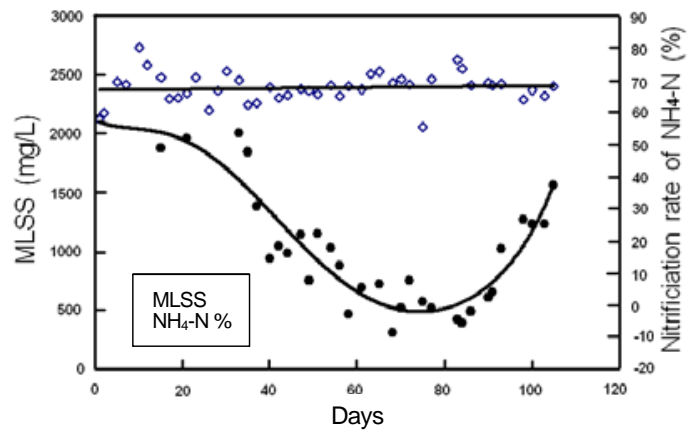

Fig. 2. MLSS pattern in SBSBR during initial acclimation period.

이후부터 빠른 속도로 감소하면서 약 80 일경에 $500 \mathrm{mg} / \mathrm{L}$ 수준 이하로 까지 감소하였으며 이후 다시 빠른 속도로 증가하기 시작하였다. 반면 $\mathrm{NH}_{4}-\mathrm{N}$ 의 질산화율은 초기 운전일수 경과에 따 른 반응조내 MLSS 농도 변화에 상관없이 일정 하게 유지되었다. 이러한 현상으로 미뤄 반응 조내 MLSS 농도의 감소는 운전일수가 경과함 에 따라 미생물이 생물막 media (ring lace)에 부착하면서 나타난 결과인 것으로 판단되었으 며 실제 침수된 ring lace에 biofilm이 점차 형성 되는 것을 목격할 수 있었다. 80 일 이후부터의 
MLSS 농도 증가현상은 이 시점에서 biofilm의 형성이 안정화 단계에 접어들었다는 것을 의미 하는 것으로 MLSS 농도의 증가는 반응조내에 서의 미생물들의 지속적인 증가 및 biofilm의 형성과 탈리에 의한 것으로 판단되었다. 반응 조내에서 충분한 biofilm 형성이 이루어졌다고 판단된 110 일 이후부터 HRT 15일 조건하에서 $\mathrm{SBSBR}$ 의 오염물질 제거효율과 특성을 시험하 였다 (Table 2, operation I). 평균 $\mathrm{NH}_{4}-\mathrm{N}$ loading rate은 $54.6 \mathrm{~g} / \mathrm{m}^{3}$.d 이었으며 SBSBR에서의 $\mathrm{NH}_{4}$ $-\mathrm{N}$ 질산화효율은 평균 약 $96.7 \%$ 이었다. 그러 나 $\mathrm{TN}$ (as $\mathrm{NH}_{4}-\mathrm{N}$ plus $\mathrm{NO}_{\mathrm{x}}-\mathrm{N}$ )의 제거효율은 비 교적 낮은 $68 \%$ 수준을 나타내어 반응조내에서 탈질이 활발히 진행되지 않았음을 알 수 있었 다. 낮은 탈질율은 유입수내 유기화합물의 부 족에도 불구하고 추가탄소원을 사용하지 않았 기 때문인 것으로 판단되었다. 용해성 인의경 우 운전기간중 제거가 이루어지지 않고 오히려 유출수내 용해성 인의 농도가 유입수의 농도보 다 평균 $15 \mathrm{mg} / \mathrm{L}$ 증가하는 것으로 나타났다. 이 러한 결과는 생물학적 인 제거 공정에서 실질 적으로 인의 제거는 슬러지 폐기로 이루어지는 데 SBSBR 운전동안 아무런 슬러지의 폐기가 이루어지지 않음에 따라 잉여 슬러지의 용해가 일어나고 이것이 용해성 인 증가의 원인이 되 었던 것으로 판단된다.

유입수와 유출수의 평균 $\mathrm{pH}$ 는 각 8.4 와 6.5 로 반응조내에서 크게 하락하는 것으로 나타났 다. 이러한 $\mathrm{pH}$ 의 하락은 반응조내에서의 $\mathrm{NH}_{4}$ $\mathrm{N}$ 의 높은 질산화에 의한 alkalinity 소모와 저조 한 탈질에 의한 낮은 alkalinity 회복 때문인 것 으로 판단된다. 낮은 $\mathrm{pH}$ 조건에서의 활발한 질 산화반응의 유지가 생물막 공정의 경우 가능하 며(Stankewich, 1972) 생물막 공정에서의 alkalinity 소모율은 부유성장 공정보다 낮은데(kim과 박, 2003) 그 이유는 질산화 반응이 일어나는 포기 단계에서도 생물막 내부안쪽에 형성되어있는 무산소 Zone에서 동시적인 탈질반응이 일어나 기 때문이다. 또한 일반적으로 생물막 공정에 서 유기물질이 미생물에 의해 대사될 때 alkalinity가 생성되기도 하기 때문이다(Remoudaki, 2003).
$\mathrm{SBSBR}$ 과 연계되어 운전할 sandfilter의 운전 형태를 결정하기 위하여 수직형과 경사형 두 유형의 sandfilter를 마련하고 $\mathrm{NO}_{\mathrm{x}}-\mathrm{N}$ loading rat 에 따른 탈질율을 분석한 결과 (Fig. 3, 4) 수직 형에서 $19 \%$, 경사형에서 $3.8 \%$ 로 수직형에서 약 5 배정도 높은 것으로 나타났다. 수직형에서 의 높은 오염물질 제거효율은 유입수의 흐름에 있어 수직형은 하-상류로 여재와 완전 접촉이 이루어지나 경사형에서는 여재와 접촉하지 않 는 공간이 존재하여 상대적으로 여재와의 접촉 시간이 적었기 때문인 것으로 판단되었다. 이 러한 결과에 의거 sandfilter의 운전 형태로 수 직형을 택하여 $\mathrm{SBSBR}$ 과 연계하고 침전과 최종 유출수의 배출시간을 제외한 모든 처리시간동 안 $105 \mathrm{~L} / \mathrm{h} \cdot \mathrm{m}^{3}$ 의 비율로 SBSBR과 sand filter간 의 내부순환을 수행하면서 시스템에서의 오염

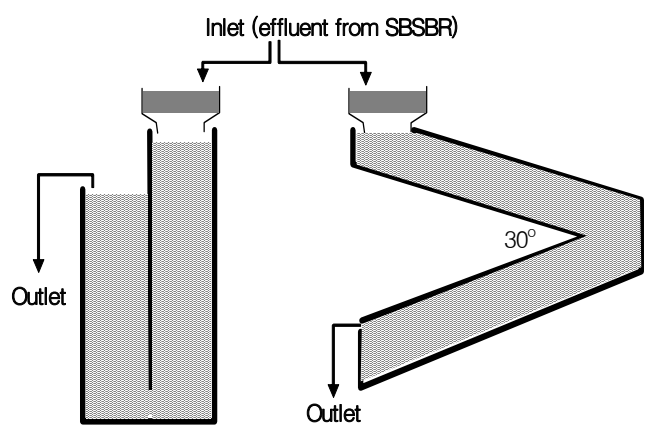

Fig. 3. Operation type of sandfilter.

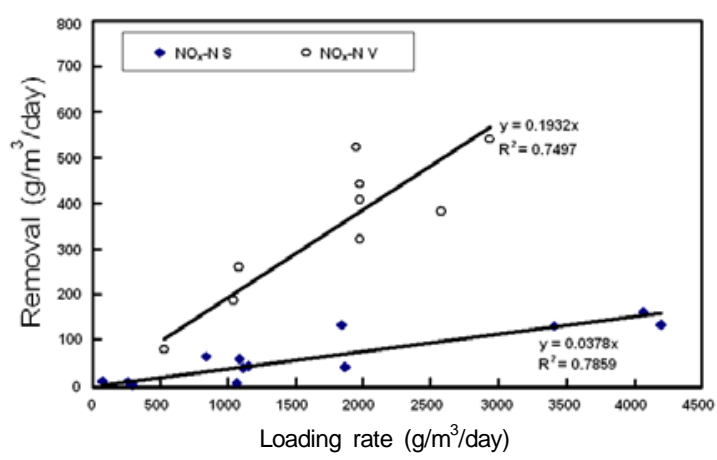

S : Slope type

V: Vertical type

Fig. 4. Denitrification performance vs operation mode of sand filter. 
물질 제거효율과 그 특성을 평가하였다 (Table 2, operation $\square$ ).

Sandfilter를 통한 내부순환을 수행하면서 처 리시스템을 operation I에서와 동일한 HRT 15 일, $\mathrm{NH}_{4}-\mathrm{N}$ loading rate $54.3 \mathrm{~g} / \mathrm{m} 3$.d 조건에서 운 전하였을 때 $\mathrm{STOC}, \mathrm{NH}_{4}-\mathrm{N}, \mathrm{TN}, \mathrm{PO}_{4}{ }^{3-}$ 의 평균 제거효율은 각각 $75 \%, 97.3 \%, 85.3 \%, 32.4 \%$ 였다. 탈질을 위한 외부탄소원이 전혀 사용되 지 않았음을 고려할 때 얻어진 질소의 제거효 율은 비교적 만족스러운 결과라 할 수 있다. 동일 운전조건에서 liquor의 내부순환없이 SBSBR 을 운전하면서 얻어진 처리효율과 비교할 때 sandfilter를 통한 내부순환시 $\mathrm{TN}$ 의 경우 약 13.5 $\%$ 정도 제거효율이 증진되었다. 얻어진 질소의 제거효율 증진은 주로 sandfilter에서의 탈질반 응에 의한 것으로 두 운전을 비교할 때 $\mathrm{NH}_{4}-\mathrm{N}$ 의 질산화율이 각각 약 $96.7 \%$ 와 $97.3 \%$ 수준으 로 거의 동일하였으나 $\mathrm{TN}\left(\mathrm{as} \mathrm{NH}_{4}-\mathrm{N}\right.$ plus $\mathrm{NO}_{\mathrm{x}}$ -N)의 제거효율은 각각 $67.8 \%$ 와 $85.3 \%$ 로 큰 차이를 보이고 있다. SBSBR 반응조내 liquor의 연속적인 내부순환으로 인해 sandfilter에 걸려 진 미세유기물입자가 가수분해 되면서 유입되 는 $\mathrm{NO}_{\mathrm{x}}-\mathrm{N}$ 의 탈질을 위한 탄소원으로 이용되었 을 것이며 이는 탈질효율 증진의 결과가 되었 을 것으로 판단되었다. Biofilter에서의 탈질능은 고유한 것이며 유입되는 mixed liquor에 산소가 존재하는 조건하에서도 탈질반응이 가능한 것으 로 보고되고 있기도 하다(Biesterfeld 등, 2003). 또한 $\mathrm{PO}_{4}^{3-}$ 의 경우에도 liquor의 내부순환이 수 행되지 않았을 때에는 오히려 증가현상이 목격 되었으나 내부순환시 약 $57 \%$ 가 제거되는 것으 로 나타났는데 이러한 용해성 인의 제거는 liquor의 내부순환으로 인한 미부착 잉여 sludge 의 지속적인 배출의 결과라 판단된다. 이러한 결과로 미뤄 sandfilter와 SBSBR 공정을 연계하 여 liquor를 내부순환시키면서 운전하는 방법은 용해성 인의 제거효율을 높일 수 있을 뿐만 아 니라 유출수내 $\mathrm{NO}_{\mathrm{x}} \mathrm{-N}$ 의 농도를 감소시켜 $\mathrm{TN}$ 의 제거효율을 높임은 물론 고도처리를 얻기 위해 외부 탄소원을 사용하는 경우 운전경비절감 효 과가 있을 것으로 판단된다. 그러나 실제 전문 인력이 부족한 농가 현장에의 적용을 위해서는 sandfilter로 mixed liquor가 유입되기 전에 고형 물을 효율적으로 제거하여 sandfilter의 막힘현 상 발생을 최소하여야 할 것으로 판단된다.

Fig. 5는 시스템에서의 질소제거 특성을 나타 낸 것이다. 유입수 농도 변화에 따른 $\mathrm{NH}_{4}-\mathrm{N}$ 부 하량 변화와 그에 따른 제거효율 및 최종 유출 수내 $\mathrm{NH}_{4}-\mathrm{N}$ 의 농도를 분석한 결과 부하량이 $60 \mathrm{~g} / \mathrm{m}^{3} . \mathrm{d}$ 수준에서 점차 $140 \mathrm{~g} / \mathrm{m}^{3} . \mathrm{d}$ 수준까지 증가함에 따라 처리효율이 감소하였으며 유출 수내 $\mathrm{NH}_{4}-\mathrm{N}$ 의 농도도 부하량 $60 \mathrm{~g} / \mathrm{m}^{3} . \mathrm{d}$ 수준에 서는 평균 약 $20 \mathrm{mg} / \mathrm{L}$ 이하였으나 부하량이 점 차 증가함에 따라 농도가 급격히 증가하는 것
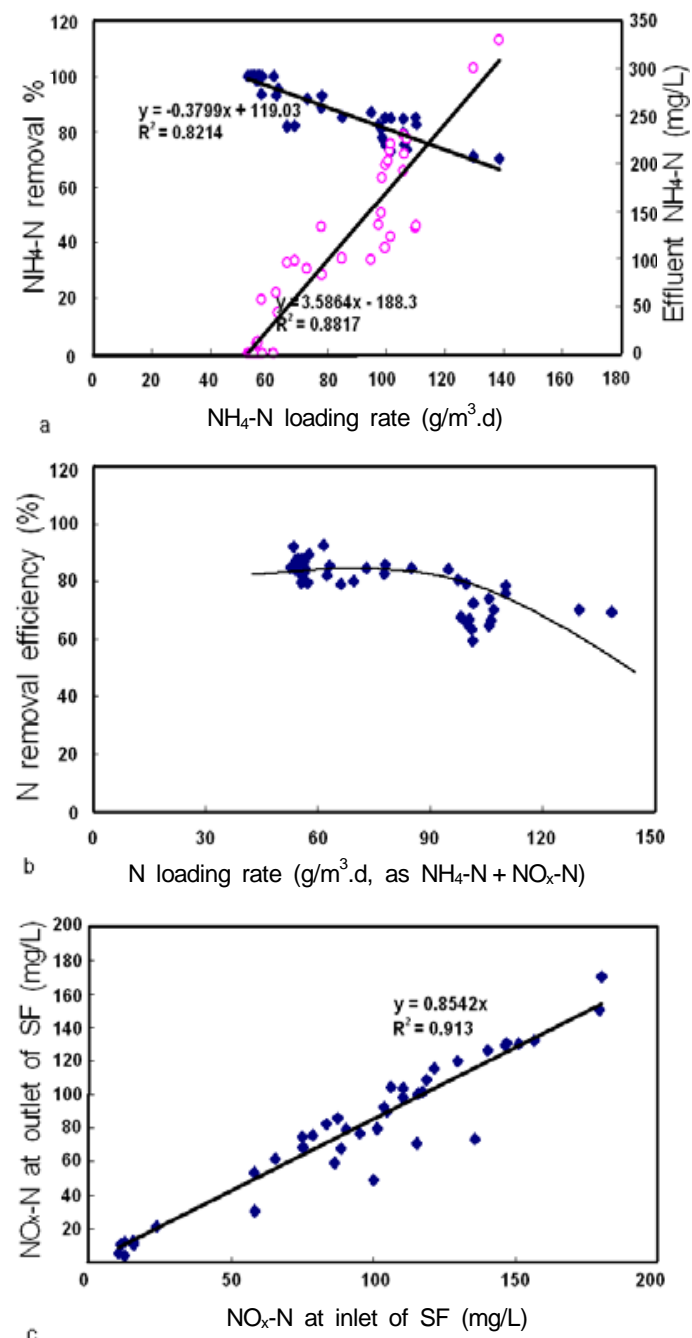

Fig. 5. $\mathrm{N}$ removal pattern in system. 
으로 나타났다(Fig. 5a). 반면 $\mathrm{NO}_{\mathrm{x}}-\mathrm{N}$ 을 고려한 질소 제거양상을 보면 부하량이 $60 \mathrm{~g} / \mathrm{m}^{3} . \mathrm{d}$ 에서 $100 \mathrm{~g} / \mathrm{m}^{3} . \mathrm{d}$ 수준까지 증가함에도 평균 $80 \%$ 이 상의 제거효율을 보였으며 부하량 $100 \mathrm{~g} / \mathrm{m}^{3} . \mathrm{d}$ 이상에서 처리 효율이 감소하는 것으로 나타나 (Fig. 5b) 본 연구에서와 같이 외부 탄소원이 전혀 사용되지 않는 운전조건에서의 내부순환 식 SBSBR-sandfilter 공정의 적정 질소 부하량 은 약 $100 \mathrm{~g} / \mathrm{m}^{3} . \mathrm{d}$ 정도일 것으로 판단되었다. Sandfilter에서의 $\mathrm{NO}_{\mathrm{x}} \mathrm{-N}$ 의 탈질효율을 살펴보면 (Fig. 5c) sandfilter를 통하여 순환되는 $\mathrm{NO}_{\mathrm{x}}-\mathrm{N}$ 중 평균 약 $15 \%$ 정도가 탈질반응에 의해 제거된 것으로 나타났다.

\section{IV. 요 약}

반응물을 연속적으로 내부 순환시키는 생물 막 연속회분식 - 모래여과 공정을 고안하고 외 부 탄소원이 전혀 사용되지 않는 조건하에서의 돈사폐수 처리특성을 평가하였다. 수직형과 경 사형 모래여과조에서의 $\mathrm{NO}_{\mathrm{x}} \mathrm{-N}$ 부하량에 따른 탈질율은 각각 $19 \%$ 와 $3.8 \%$ 로 수직형에서 5 배 정도 높은 효율을 보임에 따라 수직형태의 모 래여과조를 생물막 연속회분식 공정과 연계하 여 운전하였다. 처리공정을 HRT 15일, 내부순 환율 $105 \mathrm{~L} / \mathrm{hr}^{3}$, 평균 암모니아성 질소 부하량 $54 \mathrm{~g} / \mathrm{m}^{3}$.d 조건에서 운전하였을 때 STOC, $\mathrm{NH}_{4}$ $\mathrm{N}, \mathrm{TN}$ 의 처리효율은 각각 $75 \%, 97 \%, 85 \%$ 이 었다. 생물막 연속회분식 반응조와 모래여과조 간의 내부순환으로 $\mathrm{TN}$ 의 제거효율이 약 $14 \%$ 증진되는 것으로 나타났으며 얻어진 질소제거 효율 증진은 주로 모래여과조에서의 탈질에 의 한 것으로 밝혀졌다. 또한 용해성 인의 경우 내부순환이 수행되지 않았을 시에는 유출수내 농도가 오히려 증가하였으나 내부순환시에는 약 $57 \%$ 정도가 제거되는 것으로 나타남에 따 라 반응물의 내부순환이 용해성 인의 제거효율 증진에도 기여함을 알 수 있었다. 시스템에서 의 질소제거 양상을 분석해본 결과 최종 유출 수내의 $\mathrm{NH}_{4}-\mathrm{N}$ 은 부하량 $60 \mathrm{~g} / \mathrm{m}^{3}$.d 수준에서 약 $20 \mathrm{mg} / \mathrm{L}$ 이하로 비교적 일정하였고 부하량이 $100 \mathrm{~g} / \mathrm{m}^{3}$.d. 이상의 수준으로 상승함에도 $80 \%$
이상의 질소 제거효율을 보였다. 그러나 부하 량 $100 \mathrm{~g} / \mathrm{m}^{3} . \mathrm{d}$ 수준 이상에서부터 처리효율이 감소하는 것으로 나타나 외부탄소원이 전혀 사 용되지 않는 운전조건에서의 질소의 적정 부하 량은 약 $100 \mathrm{~g} / \mathrm{m}^{3} . \mathrm{d}$ 정도인 것으로 판단되었다.

$$
\mathrm{V} \text {. 사 사 }
$$

본 연구는 한국과학재단 연구비 지원 (R052002-000-00482-0)에 의해 수행되었으며 이에 감사드립니다. 또한 강원대학교 동물자원공동 연구소 지원에 감사드립니다.

\section{VI. 인 용 문 헌}

1. American public health association (A.P.H.A). 1995. Standard methods for the examination of water and wastewater. 19th Ed., Washington, D.C.

2. Andrea, B., Tom, J. B. and Francesc, S. 2000. Nitrification in stream sediment biofilms: the role of ammonium concentration and DOC. Wat. Res. 34(2):629-639.

3. Biesterfeld, S., Farmerb, G., Figueroac, L., Parkerd, D. and Russell, P. 2003. Quantification of denitrification potential in carbonaceous trickling filters. Wat. Res. 37:4011-4017.

4. Buitron, G., Quezada, M. and Moreno, G. 2004. Aerobic degradation of the azo dye acid red 151 in a sequencing batch biofilter. Bioresource Technology 92:143-149.

5. Cohen, Y. 2001. Biofiltration-the treatment of fluids by microorganisms immobilized into the filter bedding material: a review. Bio- resource Technology 77: 257-274.

6. Gomez, M. A., Galvez, J. M., Hontoria, E. and Lopez, J. Z. 2003. Influence of ethanol concentration on biofilm bacterial composition from a denitrifying submerged filter used for contaminated groundwater. J. Bioscience and Bioengineering 95(3):245-251.

7. Kim, D. S. and Park, M, J. 2003. Effects of media packing ration the sequencing batch biofilm 
reactor. J. Korean Environmental Sci. 12(7):791799.

8. Li, J., Xing, X. H. and Wang, B .Z. 2003. Characteristics of phosphorus removal from wastewater by biofilm sequencing batch reactor (SBR). Biochemical Engineering Journal 16:279285.

9. Ling, J. and Chen, S. 2005. Impact of organic carbon on nitrification performance of different biofilters. Aquacultural Engineering 33(2):150-162.

10. Loukidou, M. X. and Zouboulis, A. I. 2001. Comparison of two biological treatment processes using attached-growth biomass for sanitary landfill leachate treatment. Environmental Pollution 111:273-281.

11. Nakhla, G. and Farooq, S. 2003. Simultaneous nitrification-denitrification in slow sand filters. Journal of Hazardous Materials 96:291-303.
12. Remoudaki, E., Hatzikioseyian, A., Kousi, P. and Tsezos, M. 2003. The mechanism of metals precipitation by biologically generated alkalinity in biofilm reactors. Wat. Res. 37:3843-3854.

13. Stankewich, M. J. Jr. 1972. Biological Nitrification with the high Purity Oxygenation Process. Paper presented at the 27th Annual Purdue industrial Waste Conference, Purdue Univ., May 2-4.

14. Wang, B., Li J., Wang, L., Nie, M. and Li, J. 1998. Mechanism of phosphorus removal by SBR submerged biofilm system. Wat. Res. 32(9):26332638.

15. White, D. M. and Shadabel, W. 1998. Treatment of cyanide waste in a sequencing batch reactor. Wat. Res. 32(1):254-257.

(접수일자 : 2006. 11. 23. / 채택일자 : 2007. 3. 7.) 